\title{
Business Education Students' Opinion on the Benefits and Challenges of E-Assessment in Universities in Edo State
}

\author{
Dr. (Mrs.) Henrrietta Abhameso OLUMESE \\ Department of Vocational and Technical Education, Faculty of Education, \\ University of Benin, Benin City, Edo State
}

\begin{abstract}
The study examined the Business Education students' opinion on the benefits and challenges of E-assessment in Universities in Edo State. Two research questions were raised to guide the study. The descriptive survey research design was adopted in the study. The population was made up of 226 (100 and 200 level) Business Education students from the two public universities offering Business Education in Edo State. The entire population of the students was used. The structured questionnaire titled: Benefits And Challenges Of E-assessment Questionnaire (BACOEQ) with 14 items was developed by the researchers and was structured in a 4-point Likert scale: Strongly Agreed (4), Agreed (3), Disagreed (2) and Strongly Disagreed (1).The instrument was validated by the experts in the field and the Cronbach's Alpha was used in obtaining a reliability coefficient of 0.88 . The researcher was able to retrieve 178 copies of the questionnaires from the respondents and they were subjected to further statistical analysis using Mean and Standard Deviation. The Statistical Packages for Social Sciences (SPSS) version 22 was used for this purpose. The findings of the study revealed the following: the E-assessment is relevant in assessing the Business Education students in the public universities in Edo State and there are numerous challenges facing the E-assessment such as poor funding, inadequate infrastructure and facilities. Based on the findings, a major recommendation advanced was that institutions of higher learning should consciously and actively utilize modern computer technologies in assessing and monitoring the progress of their students.
\end{abstract}

Keywords: E-assessment, Paper-Pencil Test, Computer and Business Education

DOI: $10.7176 / \mathrm{JESD} / 10-10-04$

Publication date:May $31^{\text {st }} 2019$

\section{Introduction}

Business education is one of the scholarly fields in Specialized and Professional Instruction (TVE). According to Imeokparia and Ediagbonya (2014), Business Education is an aspect of education that is geared at equipping the learners with business and education competencies. These refer to skills, knowledge and attitude needed to effectively function in the world of work either as an employee or an employer (job/wealth creator). For the objectives of the programme to be acknowledged, there is requirement for the advancement of the students to be observed as evaluation. This thought has educated the need to investigating distinctive types of evaluation procedure with a view to moving with the mechanical pattern in the globe. Prior to this mechanical age, Business education understudies had regularly been evaluated through the Paper-Pencil Test (PPT) or the customary method of appraisal. That is, utilizing paper and pencil over the span of looking at and observing the advancement of the understudies. Be that as it may, with the rise of new advancements, different methods of evaluation like the Eassessment have been presented. The utilization of PC innovation in instructive evaluation has a decades-in length history. PCs were at first received for appraisal in the 1970s keeping in mind the end goal to lessen human raters' scoring outstanding task at hand. From that point forward, evaluation has advanced related to mechanical progressions. It should noticed that the essential focal point of E-assessment isn't growing new appraisal devices yet enhancing learning by utilizing new assessment technologies (Baker \& O'Neil, 1995; Pellegrino, Chudowsky, \& Glaser, 2001; Shute, 2009).

As indicated by Thurlow, Lazarus, Albus and Hodgson (2010), the E-assessment has developed as one of the ongoing 'imaginative and businesslike' ways to deal with evaluations most sought after by states. The E-assessment is viewed as an impetus for change, bringing change of learning, instructional method and educational program in instructive establishments (Scheuermann \& Pereira, 2008). E-assessment alludes to appraisal techniques and practices that stress the job of data innovation with respect to estimating understudies' learning. As indicated by Graff (2004), E-assessment can be essentially characterized as a strategy for utilizing Information and Communication Technologies (ICTs) for assessment related exercises. Hricko and Howell (2006) focused on that E-assessment must guarantee that the device consolidates the components of customary evaluation, fits the method of conveyance, and honestly estimates the coveted results. In spite of not continually addressing these requirements, E-assessment has expanded in ubiquity as of late and has experienced various improvements.

As per Parshall, Splash, Kalohn and Davey (2002), E-assessment apparatuses were initially created by specialists by just changing over test papers to an electronic configuration. Albeit conventional Paper-Based Testing (PBT) has for quite some time been viewed as obsolete and not in accordance with the most recent methods or advances in innovation and appraisal forms; tragically that some E-assessment still sustains these old and 
obsolete practices. Regardless of this, E-assessment can possibly include esteem, upgrade limit, and add to the level of responsibility and validity of the evaluation procedure. To set up a substantial and dependable Eassessment, the Global Rules on E-assessment (International Test Commission, 2004) expressed that comparable test scores ought to be built up for the regular Paper-Based Testing (PBT) and its electronic mode. This arrangement of testing models is bolstered by the established genuine score test hypothesis - the premise of PC based and paper-based testing (Allen \& Yen, 1979). Under this hypothesis, a test taker who steps through a similar exam in the two modes is relied upon to acquire about indistinguishable test scores (Chua, 2012). The benchmarks are likewise upheld by observational investigations (Organisation for Economic Co-operation and Development (OECD, 2010)

The current innovative move in the nation has proceeded to revolutionalize the instructive subsector and this has required the use of PC advances in surveying students and observing their advancement. This has likewise showed in the technique for appraisal used by specialists in evaluating Business education understudies towards more prominent profitability; the will inevitably advance their employability. Specialists have investigated the advantages of the E-assessment in evaluating understudies' scholarly execution. Studies have uncovered that scholarly establishments spare a great deal of cash by moving from the PPT to the E-assessment (Chua, 2012). The E-assessment has the propensity of decreasing the expense related with the generation of examination booklets and question papers for examinations. Studies have similarly underscored the speed at which business education understudies' outcomes are discharged and such is considered as an extraordinary advantage of E-assessment. With the E-assessment, Business education understudies can get brisk criticism on their exhibitions and this will go far in repositioning the mentality of the understudies (Organisation for Economic Co-operation and Development (OECD, 2010). With this quick criticism, understudies currently represent their activities; and they never again ascribe their poor execution to course speakers/inspectors. E-assessment as an evaluation mode has the inclination of checking the abundances of understudies who might need to be engaged with a few behaviours in spite of the standards administering the best possible direct of examinations. That is, the level of examination negligence is checked with E-assessment mode set up.

Notwithstanding the advantages of the E-assessment, it has similarly been censured by researchers; and a portion of the difficulties confronting the usage of the E-assessment include: fund, insufficient offices/foundation, control issue, labour lack, availability/organize issue and upkeep challenge. The execution of the E-assessment includes sensible venture of capital for its underlying start-up. Cash is an asset that can be utilized to secure different assets. Most foundations think that it's hard to embrace and execute the E-assessment on account of restricted assets. Subsidizing is a noteworthy thing that necessities be put into thought in the execution of eassessment venture. The majority of the offices and framework required are procured with reserves. The insufficiency of offices like work area, workstations and other system offices has been recognized as a noteworthy test confronting the E-assessment. The offices will work better when there is consistent power supply. The 'epileptic power' supply being experienced will clearly influence the execution of the E-assessment.

Notwithstanding the advantages of the E-assessment featured above, perception has similarly demonstrated a few difficulties confronting the E-assessment execution. Most teachers and understudies have similarly communicated question on the capacity of the E-assessment in surveying the totality of Business education abilities. In light of the above introduce, the analyst is occupied with researching the Business education understudies' supposition of the E-assessment in the colleges in Edo State.

\subsection{Research Method}

This study utilised the descriptive survey design since it was basically an enquiry into the Business Education students' opinion on the benefits and challenges of the E-assessment in the universities in Edo State. The population of this study consisted of all the 100 and the 200 level Business Education students that were in the two public Universities offering Business Education in Edo State. The total population was 226 respondents. Since the entire population were used, there was no sampling technique. Therefore, the sample size was 226 . The instrument used for this study was a structured questionnaire. The questionnaire was used in eliciting information from the respondents and it was titled: Benefits And Challenges Of E-assessment Questionnaire (BACOEQ). It was divided into two parts - A and B. Part A was made up of the demographic variables of the respondents such as sex and the institution; while Part B was made up of 14 opinion statements designed in a 4-Point Likert Rating Scale showing Strongly Agreed (SA), Agreed (A) Disagreed (D) and Strongly Disagreed (SD), weighted 4, 3, 2 , 1 respectively. The instrument was subjected to content and face validity. It was given to experts in Business Education in the Faculty of Education, University of Benin, Ekpoma and their inputs to the draft instrument were incorporated into the final questionnaire. The Cronbach's Alpha was used in ascertaining the reliability of the instrument. The instrument was administered to 20 students in Business Education in Delta State University, Abraka, who were not part of the population. The reliability yielded a coefficient of .88 . The researcher utilised the face to face method of data collection. The researcher was only able to retrieve 178 copies of the questionnaire from the respondents which was equivalent to 79 per cent retrieval rate. The Statistical Packages for Social Sciences (SPSS) 
Version 22.0 was used in analyzing the data gathered. The descriptive statistic was used in answering in the research questions. Mean and standard deviation were used in answering the two research questions. Any mean value of 2.50 and above was considered as agreed while below 2.50 was considered as disagreed.

1.1.1 Results of Research

The data analysis for the research question was carried out using mean and standard deviation and the result is presented in tables $1-2$.

Research Question 1: what is the opinion of the Business Education students on the benefits of the E-assessment in assessing them in universities in Edo State?

Table 1

Means and Standard Deviation on the Benefits of the E-assessment

\begin{tabular}{lllll}
\hline S/N & Items & Mean & SD & Remark \\
\hline 1. & E-assessment facilitates the prompt release of Business education students & 3.10 & .81 & Agreed \\
& $\begin{array}{l}\text { assessment scores. } \\
\text { 2. }\end{array} \quad \begin{array}{l}\text { It reduces to the barest minimum the cost associated with producing question } \\
\text { papers in traditional exam setting. }\end{array}$ & 2.87 & .94 & Agreed \\
3. & The incidence of examination malpractice is reduced in examination venues. & 3.04 & 1.05 & Agreed \\
4 & The students are motivated by the immediate feedback from the E-assessment. & 2.89 & 1.00 & Agreed \\
5. & It level of distractions from invigilators/supervisors is reduced. & 2.95 & 1.01 & Agreed \\
6. & The level of intimidation from lecturers is reduced due to E-assessment. & 3.10 & .94 & Agreed \\
7 & It strengthens the computer skills possessed by Business education students. & 3.25 & .94 & Agreed
\end{tabular}

\section{Cluster}

$3.03 \quad 0.96 \quad$ Agreed

The Table 1 reveals that the mean responses ranged from 2.87 to 3.25 while the standard deviation ranged from 0.81 to 1.05 . The Table reveals that the respondents rated all the items above 2.5, which was the mean score for decision making. Since the cluster mean was 3.03 and it was above the criterion mean value of 2.5 , it reveals that the E-assessment was relevant in assessing the Business Education students in Edo State.

Research Question 2: what is the opinion of the Business Education students on the challenges of the E-assessment in assessing them in universities in Edo State?

Table 2

Mean and Standard Deviation on Challenges of the E-assessment

\begin{tabular}{lllll}
\hline S/N & Items & Mean & SD & Remark \\
\hline 1. & The high initial cost required in commencing E-assessment project is a & 3.20 & .87 & Agreed \\
challenge to E-assessment & & & \\
2. & $\begin{array}{l}\text { This mode of assessment may pose problem to Business education students } \\
\text { with low computer skills. }\end{array}$ & 3.11 & 1.00 & Agreed \\
3. $\quad \begin{array}{l}\text { This mode of assessment may not be able to assess the mastery of some } \\
\text { practical skills }\end{array}$ & 3.07 & 1.06 & Agreed \\
4. $\quad \begin{array}{l}\text { Business education students may be psychologically affected due to the } \\
\text { immediate release of their results. }\end{array}$ & Agreed \\
5. The financial resources needed in maintaining E-assessment facilities is a & 3.26 & .94 & Agreed \\
challenge to the assessment mode. & The unsteady power supply experienced in this part of the world is a challenge & 3.34 & .92 & Agreed \\
to E-assessment project. & The inadequacy of committed human resources is a challenge to the & 3.38 & .87 & Agreed
\end{tabular}
implementation of E-assessment.

$3.19 \quad 96 \quad$ Agreed

The Table 2 above reveals that the mean responses ranged from 2.95 to 3.38 while the standard deviation ranged from .87 to 1.06 . The table reveals that the respondents rated all the items above 2.5 , which was the mean score for decision making. Since the cluster mean was 3.19 and it was above the criterion mean value of 2.5 , it reveals that all the items were challenges militating against the implementation of the E-assessment in assessing the Business Education students in the universities in Edo State.

\subsubsection{Discussion of Findings}

The analysis of the research question 1 revealed the benefits of E-assessment to Business Education students. It revealed that the speedy release of Business education students' result is a benefit of E-assessment. This finding corroborates the findings of the Qualifications and Curriculum Development Agency (QCA, 2005) where it was concluded that E-assessment could provide timely feedback to inform future teaching and learning. The finding also revealed the financial resources that could be saved by not producing examination materials. This also corroborates the findings of Bridgeman (2009), Van Lent (2009) and Bennett (2003) where the authors concluded 
that the E-assessment was less expensive than printing and mailing large quantities. This position was equally supported by Thurlow, Lazarus, Albus and Hodgsn (2010) where they concluded that since the early 2000s, the Eassessment seemed to have advantages over paper and pencil testing, both for the states that run the assessment programmes and for the students who participate in them. More efficient delivery and grading, being cost effective and using less resources are all advantages of the E-assessment.

The analysis of research question 2 revealed that the E-assessment was faced with several challenges. It revealed that funding was the major challenge in the use of the E-assessment. This finding corroborates the finding of Education Commission of the States (2010) where it was concluded that schools were unable to provide the latest version of the tablets and the smart phones. The findings also revealed that inadequacy of infrastructure and facilities were challenges in the E-assessment implementation. This also corroborates the findings of KikoPapadakis \& Kolleas (2009) where the authors found that inadequacy of computer hardware and software were challenges in the E-assessment implementation. This finding corroborates the findings of Kozma (2009) and Kyllonen (2009) where the authors revealed that connectivity was a major challenge in the E-assessment implementation. This finding also revealed that the inadequacy of committed human resources staff was also a challenge in the E-assessment implementation. This finding corroborates the findings of Lee (2009) and Gamire and Pearson (2006) where the authors stressed the need for the employment of more staff to be able to manage Eassessment project towards maximizing its potentials.

1.1.3 Conclusion

This study had carefully surveyed the Business Education students' opinion of the E-assessment in universities in Edo State. Based on the findings arising from the study, it was therefore concluded that the E-assessment is beneficial in assessing Business education students in this era of technological advancement and dynamism in testing in universities in Edo State. It concluded equally that there are numerous challenges facing the E-assessment assessment in these universities in Edo State.

\subsubsection{Acknowledgement}

The researcher wishes to express great thanks and to acknowledge all authors whose research materials helped in the course of undertaking this research.

\section{References}

Allen, M. J. \& Yen, W. M. (1979). Introduction to measurement theory. Monterey, CA: Brooks/Cole.

Baker, E. L., \& O'Neil, H. F., Jr. (1995). Computer technology futures for the improvement of assessment. Journal of Science Education and Technology, 4(1), 37-45.

Bennett, R. E. (2003).Online Assessment and the Comparability of Score Meaning. Educational Testing Service, Princeton, NJ. Retrieved from http://www.ets.org/Media/Research/pdf/RM-03-05-Bennett.pdf.

Chua, Y. P. (2012). Replacing paper-based testing with E-assessmenting in assessment: are we doing wrong? Social and Behavioural Sciences, 64, $655-664$.

Education Commission of the States (2010)Assessment: Computer-Based. Retrieved from http://www.ecs.org/html/issue.asp? issueID $=12 \&$ subIssueID $=76$

Graff, M. (2004). Cognitive style and attitudes towards using online learning and assessment methods. Electronic Journal of e-Learning. 2(2), 34-42.

Gamire, E., \& Pearson, G. (Eds.). (2006). Tech Tally: Approaches to Assessing Technological http://www.qca.org.uk/libraryAssets/media/6929_factsheet_E-assessment.pdf

Hricko, M., \& Howel, S. L. (2006). Online assessment and measurement: Foundations and challenges. Hershey, PA: Information Science Publishing.

Imeokparia, P. O., \& Ediagbonya, K. (2014). Assessment of Business Education Students' Enrolment Trend in University of Benin. European Journal of Educational Studies, 6(3), 87-98.

International Test Commission (2004) International Guidelines on Computer-Based and Internet-Delivered Testing. Retrieved January 21, 2011 from http://www.intestcom.org/itc_projects.htm.

Kikis-Papadakis, K., \& Kollias, A. (2009). Reflections on Paper-and-Pencil Tests to Assessments: Narrow and Broadband Paths to 21 st Century Challenges. In F. Scheuermann \& J. Bjórnsson (Eds.). The Transition to Computer-Based Assessment: New Approaches to Skills Assessment and Implications for Large-Scale Testing. Luxembourg: Office for Official Publications of the European Communities Literacy. Washington, DC: The National Academies Press.

Kozma, R. (2009). Transforming Education: Assessing and Teaching 21st Century Skills.

Assessment Call to Action. In F. Scheuermann \& J. Bjórnsson (Eds.). The Transition to Computer-Based Assessment: New Approaches to Skills Assessment and Implications for Large-Scale Testing. Luxembourg: Office for Official Publications of the European Communities Literacy. Washington, DC: The National Academies Press.

Lee, M. (2009). CBAS in Korea: Experiences, Results and Challenges. In F. Scheuermann \& J. Bjórnsson (Eds.). The Transition to Computer-Based Assessment: New Approaches to Skills Assessment and Implications for 
Large-Scale Testing. Luxembourg: Office for Official Publications of the European Communities Literacy. Washington, DC: The National Academies Press.

Organisation for Economic Co-operation and Development (OECD,2010) PISA computer-based assessment of student skills in science. Retrieved from http:/www. oecd.org/publishing/corrigenda $\mathrm{n} 21$ December, 2011)

Parshall, C. G., Spray, J. A., Kalohn, J. C. \& Davey, T. (2002). Practical considerations in computer-based testing. Springer.

Pellegrino, J., Chudowsky, N., \& Glaser, R. (2001). Knowing what students know. Washington, DC: National Academy Press.

Qualification and Curriculum Development Agency (QCA Factsheet (2005) QCA leading the way in E-assessment, Retrieved from http://www.qca.org.uk/libraryAssets/media/6929_factsheet_E-assessment.pdf

Scheuermann, F., \& Pereira, A. G. (2008). Towards a Research Agenda on Computer-based Assessment Challenges and Needs for European Educational Measurement. JRC Scientific and Technical Report,23306 EN.

Shute, V. J. (2009). Simply assessment. International Journal of Learning, and Media, 1(2), 1-11

Thurlow, M., Lazarus, S. S., Albus, D., \& Hodgson, J. (2010). E-assessmenting practices and considerations (Synthesis Report No. 78). Minneapolis: University of Minnesota, National Centre on Educational outcomes.

Van Lent, G. (2009). Risks and benefits of CBT versus PBT in high-Stakes testing: Introducing key concerns and decision making aspects for educational authorities. In F. Scheuermann \& J. Bjórnsson (Eds.). The Transition to Computer-Based Assessment: New Approaches to Skills Assessment and Implications for Large-Scale Testing. Luxembourg: Office for Official Publications of the European Communities Literacy. Washington, DC: The National Academies Press. 